\title{
PENGARUH NILAI CERITA ANAK DAN KESUSASTERAAN DALAM MENCIPTAKAN PENDIDIKAN HUMANIS BAGI ANAK INDONESIA
}

\section{Galuh Nur Rohmah}

Dosen Jurusan Bahasa dan Sastra Inggris

Fakultas Humaniora dan Budaya, Universitas Islam Negeri (UIN) Malang.

Jalan Gajayana No. 50 Telepon (0341) 551354, Faksimile (0341) 572533 Malang 65144

\begin{abstract}
Child stories and literary works have both recreative characteristics and humanity values such as personality moral, social moral and religious moral which can shape children's ideal characteristics as a potential and strategic asset to help them to be civilized generation. The efforts to dig up the values from that two valuable sources are needed and the most possible way is through teaching the children how to appreciate child stories and literary works.
\end{abstract}

Key words

Child stories, literary work, humanity values 


\section{Pengantar}

Tatkala kita menyaksikan tayangan televisi, membaca surat kabar, dan mendengarkan berita radio. Ada keterhenyakan yang luar biasa bila kita mendapatkan adanya anak yang melakukan pembunuhan, pelecehan seksual dan kriminalitas lainnya seperti mengedarkan obat-obatan, merampok dan lain sebagainya. Pertanyaan yang seketika itu muncul adalah sudah tidak mampukah orangtuanya, sekolah dan lingkungannya mendidik mereka? Atau sudah hilangkah nilai-nilai kemusiaan dan moral pada diri anak tersebut?

Fenomena di atas menarik sekali untuk dikaji mengingat mereka adalah generasi yang akan membangun Indonesia di kemudian hari. Banyak sekali upaya yang mungkin dan bisa dilakukan untuk menciptakan pendidikan yang humanis bagi anak Indonesia sehingga mereka dapat menjadi individu yang bermoral, bijaksana dan berbudi sebagai asset untuk mewujudkan masyarakat yang berperadapan.

Salah satu tawaran upaya tersebut di atas adalah menciptakan wadah bagi anak Indonesia untuk mengapresiasi cerita rakyat dan atau karya sastra lainnya dengan cara mengenalkan sastra sejak mereka berada di tingkat pendidikan yang masih dasar. Upaya tersebut secara tidak langsung juga dapat meningkatkan kemampuan membaca anak Indonesia yang selama masih rendah (versi world bank) di mana hal ini menjadi salah satu indikator gagalnya pendidikan kita.

Tulisan ini bukan bertujuan untuk menitikberatkan pada kemampuan dan kebiasaan membaca karena penulis merasa yakin bahwa kedua hal tersebut dapat dicapai dengan seringnya seseorang membaca. Lebih jelasnya penulis mengajak pembaca untuk melihat ulang peranan cerita rakyat dan atau karya sastra, yang selama terkesan dipinggirkan, sebagai upaya untuk menciptakan pendidikan yang humanis bagi anak Indonesia. 
Mukhlas (Jawa Pos, 23 Juli 2002) mengungkapkan bahwa siswa SD di Indonesia sudah seharusnya diperkenalkan sejak dini dengan karya-karya sastra, mengingat di dalam karya sastra banyak nilai kemanusiaan yang dapat diambil manfaatnya. Seperti halnya di luar negeri, kecintaan terhadap karya sastra sudah berlangsung lama. Anggapan bahwa sastra identik dengan moral bukanlah tanpa alasan, seperti juga filsafat dan agama, sastra juga mempelajari masalah kemanusiaan. Dengan cara yang berbeda ketiganya berupaya menumbuhkan jiwa humanities atau humanitat, yakni jiwa yang halus, manusiawi dan berbudaya. Hal itu relevan sekali dengan gagasan agar sastra dijadikan sarana pendidikan humaniora (Sumardjo, 1984: 80).

Sastra adalah dunia yang bersifat dinamis, relatif, dan bukan eksklusif sehingga membuka peluang bagi anak Indonesia untuk menjadi seseorang yang memiliki pola pikir yang kritis tanpa harus melupakan aspek-aspek humanisme. Kedinamisan sastra dapat juga ditafsirkan bahwa sastra itu tidak hanya dapat menciptakan situasi yang menyenangkan atau menghibur untuk dibaca dan dipelajari. Sebagai salah satu produk karya sastra cerita rakyat memiliki beberapa peranan penting bagi anak.

Suwigyo dan Harsiati (1999: 50) menyatakan bahwa secara konkret cerita anak berguna dalam hal: (a) sumber pengetahuan, dalam hal ini anak dapat menggali pengetahuan baru berupa bagaimana menghadapi masalah, bagaimana menjadi orang yang baik, bagaimana harus bersikap dan sebagainya, (b) belajar berkomunikasi, setelah mengikuti alur cerita sebuah karya sastra seseorang dapat mencontoh bagaimana cara bermonukasi yang baik dengan orang lain, (c) bentuk identifikasi diri, karena di dalam sebuah cerita disajikan tokoh-tokoh yang baik dan buruk, sehingga seseorang dapat mengidentifikasi bahwa saya tidak ingin menjadi individu yang jelek dan dapat mengidentifikasi bahwa kepribadian yang baik dapat menguntungkan bagi kita, (d) pematangan mentalemosional, hal ini dapat dilihat dari kondisi di mana seseorang akan lebih bijak dalam bertindak, (e) peningkatan motivasi, utamanya 
motivasi untuk mempunyai teman banyak dengan selalu berbuat baik, bersikap baik dan lain-lain, (f) pemenuhan harapan sosial, seseorang akan mempunyai harapan untuk menjadi sosok yang dapat berguna bagi lingkungannya,

(g) pengembangan intelektualitas, secara otomatis seseorang jauh lebih cermat dalam menghadapi sesuatu dan dapat memecahkan masalah dengan tepat dan (h) pengembangan kepribadian anak, cerita anak membantu membentuk individu yang memiliki pribadi yang matang.

Sehubungan dengan upaya pembentukan sumber daya manusia muda Indonesia (terutama usia anak sekolah dasar), cerita anak diberi peranan penting dan strategis. Hal itu tampak dalam pokok-pokok kebijakan pembinaan generasi muda, GBHN 1993 seperti yang dikutip Suwignyo dan Harsiati dalam Ali (1991). Dalam beberapa butir kebijakan antara lain ditekankan penting dan perlunya pembinaan anak-anak dan remaja sebagai pemegang masa depan bangsa dengan moral luhur dan berbudaya. Terinspirasikan oleh kondisi tersebut di atas, maka upaya menguak kembali nilainilai yang terkandung dalam cerita anak sangatlah menarik untuk dikaji.

\section{Nilai-nilai Cerita Anak}

Dewasa ini kita dapat dengan mudah menemukan cerita anak dalam berbagai macam bentuk yang kita kehendaki. Ketika kita mendatangi sebuah toko buku, kita akan menjumpai hamparan buku cerita anak dan kalaupun kita menginginkan dalam bentuk yang berbeda kita juga telah disuguhkan cerita anak dalm bentuk CD.

Terlepas dari kemudahan tersebut, hal yang paling penting adalah menguak nilai-nilai yang terkandung di dalamnya. Penelitian yang dilakukan Suwignyo dan Harsiati (1999) telah mendapatkan temuan berupa saratnya kandungan nilai-nilai yang terkandung di dalam cerita anak yang dapat dijadikan media untuk menciptakan generasi yang utuh baik spiritual maupun non spiritual dan untuk menciptakan pendidikan yang manusiawi. 
Secara garis besar, dari cerita anak yang ada baik yang berasal dari negeri kita maupun yang berasal dari negeri lain, dapat ditarik nilai-nilai universal berupa: kandungan nilai domain moral kepribadian, kandungan nilai domain moral social dan kandunagn nilai domain moral religius.

\section{Kandungan Nilai Domain Moral Kepribadian}

Ada enam taksonomi nilai domain moral kepribadian, yaitu:

1. Kehati-hatian dalam bertindak yang meliputi kehatian-hatian dalam bertindak agar tidak mencelakai diri sendiri dan orang lain, kehati-hatian dalam menilai dan memutuskan sesuatu, kehati-hatian agar tidak terpancing oleh hal-hal yang tidak menyenangkan.

2. Kejujuran/ketidakjujuran yang meliputi sikap ketidakjujuran menimbulkan saling curiga dan keresahan, kebohongan dipergunakan asal untuk kebaikan dan kebohongan itu pada dasarnya menimbulkan kecelakaan.

3. Keberanian terdiri atas sikap keberanian mengemukakan pendapat, melawan kezaliman, mempertahankan sikap yang benar dan keberanian menerima kenyataan.

4. Kekritisan dan kekreatifan yaitu sikap kekritisan dan kekreatifan mengerjakan masalah actual, menciptakan dan mengembangkan peralatan yang bermanfaat baik bagi diri sendiri maupun orang lain.

5. Kerendahatian meliputi sikap tidak membesar-besarkan kebaikan yang telah diperbuat.

6. Kebertanggungjawaban yaitu tidak putus asa dalam mengerjakan atau mempelajari sesuatu, tidak cengeng dan tidak lekas meminta pertolongan dalam menghadapi suatu persoalan. 


\section{Kandungan Nilai Domain Moral Sosial}

Ada tujuh taksonomi nilai domain moral sosial, yaitu:

1. Penghormatan Kepada Orang Lain meliputi komponen nilai hormat kepada atasan dan hormat kepada yang memiliki kelemahan.

2. Kebekerjasamaan meliputi komponen bekerja sama untuk mengalahkan lawan dan bekerja sama untuk mencapai hasil yang baik.

3. Nilai kesolideran terhadap kawan meliputi komponen menolong kawan yang sakit, menghibur kawan yang susah dan menasehati kawan yang melakukan kesakahan.

4. Nilai Pengakuan Hak Orang Lain meliputi komponen merampok akan dihukum, mengambil hak orang lain akan celaka, dan mencuri untuk tujuan baik.

5. Taksonomi nilai kemusyawarahan meliputi komponen nilai bermusyawarah untuk memecahkan masalah bersama, bermusyawarah untuk tidak saling menyalahkan.

6. Taksonomi kedisiplinan meliputi komponen nilai sikap tepat waktu, bersedia antri.

7. Taksonomi kasih sayang meliputi komponen persahabatan dengan hewan, tidak mencelakakan hewan tak bersalah dan menolong hewan yang menderita.

\section{Kandungan Nilai Domain Moral Religius}

Hanya ada dua taksonomi nilai moral religius, yakni mempercayai adanya kematian dan mempercayai adanya kehidupan setelah mati (akhirat). Nilai religius mengarah pada penghayatan Tuhan Yang Suci. Karakteristik manusia religius ialah mempercayai adanya Tuhan, membina hubungan dekat dengan sang Pencipta, mempercayai kekuasaan Tuhan atas makhluk ciptaan-Nya, 
mempercayai hal-hal yang ghaib yakni malaikat, kehidupan, akhirat dan sebagainya.

Manusia religius juga mempercayai kemahakuasaan sang Pencipta. Segala yang dimiliki oleh manusia, yakni keperkasaan, kekuasaan, kekuatan dan sebagainya berasal dan akan kembali kepada sang Pencipta.

\section{Faedah Cerita Anak dan Kesusasteraan bagi Pendidikan Anak}

Salah satu saran Thrax, sebagaimana yang telah dikutip oleh Abdul Wahab (1991: 35), tentang pengajaran bahasa adalah apresiasi terhadap karya sastra, dan bagian inilah yang merupakan bagian yang sangat terhormat dalam pengajaran bahasa. Saran ini didasari bahwa secara alami anak didik dapat mengemukakan kritik. Hal ini tidak berarti bahwa kita selalu ingin mencari kesalahan atau kelemahan sesuatu karya atau pikiran orang lain. Apa yang dimaksud di sini, kita mengajak anak didik mencoba memahami dan menarik kesimpulan dari hal-hal yang mereka sukai dan yang tidak.

Apresiasi sastra memberikan kemampuan kepada anak didik untuk mengukur kemampuan apa yang kita baca itu dengan pengalaman mereka sendiri, untuk memberikan tanggapan secara penuh dan sempurna. Tanggapan yang sempurna tersebut terkadang dapat menggugah perasaan yang kuat yang ada pada anak didik dan akan membimbing mereka kepada pengertian tentang pengalaman.

Cerita anak dan kesusasteraan berkontribusi positif untuk pembentukan konsep diri atau self-concept pada diri anak yang sedang dalam masa pertumbuhan dan masa perkembangan. Seperti yang dinyatakan Comstock dalam Wellek (1993: 70) menjelang masa berakhirnya masa kanak-kanak, anak-anak mulai mengagumi tokohtokoh fiksi.

Selain berkontribusi positif terhadap pembentukan konsep diri, cerita anak juga memiliki pesan -pesan tertentu yang bersifat fungsional seperti yang telah diuraikan pada bagian sebelumnya. Hal ini dikarenakan cerita anak dan kesusasteraan memiliki keterkaitan 
dengan gejala kehidupan yang melingkupinya antara lain persoalan social, politik, sejarah atau moralitas tertentu dan kemanusiaan, sehingga keduanya berupaya menumbuhkan jiwa humanities atau hemanitat yakni jiwa yang halus, manusiawi dan berbudaya.

\section{Penutup}

Dengan menelaah apa yang ada di dalam cerita anak dan kesusasteraan, kita dapat mengambil sebuah garis besar yaitu cerita anak dan kesusasteraan dengan berbagai segi kelebihan yang dimiliki utamanya kandungan nilai yang ada di dalamnya dapat digunakan sebagai media otensial dan strategis untuk menciptakan pendidikan yang humanis dan membentuk anak Indonesia yang bermoral dan berbudaya tinggi. $\square$ 


\section{DAFTAR PUSTAKA}

Jaruki, Muhammad Mardiyanto. 1993. Cerita Rakyat dari Irian Jaya. Jakarta: PT. Grasindo.

Mukhlas. 2002, 23 Juli. Pengenalan Sastra dan Mengarang Harus Dimulai Sejak SD. Jawa Pos.

Sumardjo. 1984. Memahami Kesusasteraan. Bandung: Alumni.

Suwignyo, Heri dan Harsiati, Titik. 1991. "Pokok-pokok Kebijakan Pembinaan dan Pengembangan Sastra" dalam Ali. Makalah disajikan dalam Temu Ilmiah Ilmu-ilmu Sastra Pasca Sarjana seIndonesia. Bandung, 21-22 Oktober.

1999. Nilai Kutural Edukatif Cerita Anak-anak Tayangan Televisi Indonesia. Malang: IKIP Malang Press.

Tim Penyusun Kamus Pusat Pembinaan dan Pengembangan Bahasa. 1989. Kamus Besar Bahasa Indonesia. Edisi Kedua. Jakarta: Depdikbud.

Wahab, Abdul. 1991. Isu Linguistik Pengajaran Bahasa dan Sastra. Surabaya: Airlangga University Press.

Wellek, Rene dan Austin Warren. 1993. Teori Kesusasteraan. Terjemahan Melani Budianto. Jakarta: Gramedia. 